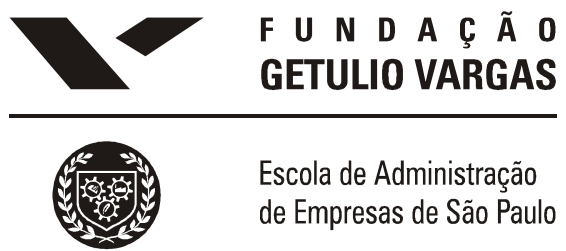

Este artigo foi traduzido e reproduzido com autorização de Academy of Management Executive, Review, Journal, or Learning and Education, periódicos de língua inglesa editados pela Academy of Management. Acesse www.aomonline.org para informações sobre Academy of Management ou assinaturas de suas publicações ou contate Susan Zaid, 235 Elm Road Briarcliff Manor, New York 10510, USA. szaid@pace.edu.

(C2005 Academy of Management. Todos os direitos são reservados. Nenhuma parte deste artigo pode ser reproduzida sem autorização escrita de Academy of Management. Obtenha autorização para reprodução e uso em sala de aula junto a Copyright Clearance Center (www.copyright.com).

\title{
GVexecutivo
}


ESPECIAL A.M.E.

\section{Modelos duplos}

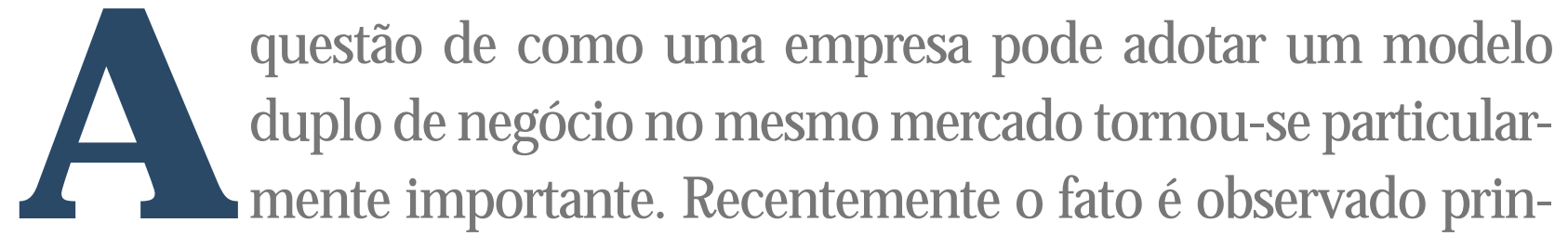
cipalmente no caso de empresas estabelecidas que sofreram o ataque de concorrentes usando estratégias competitivas radicalmente diferentes. Esteartigo, baseado na abordagem da contingência discutecomo essas empresas podem gerenciar modelos duplos de negócios sem perder o foco e maximizando as sinergias existentes.

Constantinos Markides e Constantinos D. Charitou London Business School

Considere os seguintes casos:

- Em fevereiro de 1989, a Singapore Airlines estabeleceu uma filial para competir no segmento do mercado de linhas aéreas. O riginalmente chamada de Tradewinds, mas renomeada como Silkair em 1992, a operadora de baixo custo cresceu nos últimos dez anos. A Silkair conta hoje com uma frota de 9 aeronaves e opera 117 serviços por semana para 26 destinos regionais. Apesar de competir com uma estratégia (ou modelo de negócio) fundamentalmente diferente da estratégia do tipo radial de sua matriz e dos conflitos inerentes entre as atividades das duas companhias, a Singapore Airlines obteve sucesso em transformar a Silkair em uma parte rentável e integral de sua estratégia de rede. Esse sucesso contrasta com as tentati- 
vas de diversas outras companhias aéreas com relação ao mesmo tipo de operação. Por exemplo, na última década, as tentativas da Continental Airlines (ao criar a Continental Lite), da British Airways (ao criar a GO) e da KLM (ao criar a Buzz) para competir no segmento do mercado aéreo não foram bem-sucedidas.

- Em 1992, em uma tentativa de competir com os clones dos PCs de baixo custo, a IBM lançou o Ambra - seu próprio clone, vendido a preços mais baixos sem o uso explícito da marca IBM . 0 objetivo da Ambra era imitar o modelo de venda direta da Dell sem al ienar os revendedores. Em seu lançamento, o presidente da Ambra, David Middleton, declarou que a Ambra capturaria pelo menos 10 por cento de um mercado estimado em 10 bilhões de dólares. 0 executivo da IBM afastou os temores de canibalização de vendas, argumentando que os computadores pessoais Ambra apelariam para um segmento de consumidores diferente daquele dos consumidores que compram computadores com a marca IBM. No entanto, a Ambra revelou-se um exemplo clássico do argumento de Porter (1980) de que uma companhia que tentar uma diferenciação e um jogo de baixo custo ao mesmo tempo ficará a meio caminho. Impulsionada por vendas em declínio, por um portifólio conflitante de marcas e por uma estrutura de custo sobrecarregada, a IBM fechou a Ambra em 1994. 0 fracasso da IBM em conduzir a diferenciação e os esquemas de baixo custo ao mesmo tempo está em contraste direto com o sucesso de muitas outras companhias que fizeram exatamente a mesma coisa. Companhias como a Toyota (com seu carro Lexus), a Mercedes (com seu Mercedes Classe-A), a VW (com suas marcas Skoda e SEAT), a Intel (com seu chip de baixo custo Celeron), a Gap (com sua marca Old N avy), a SMH (com o Swatch) e a N estlé (com sua filial Nespresso) são exemplos de organizações que descobriram formas de competir com sucesso por meio de estratégias de diferenciação e de baixo custo.

- No final da década de 1980, o pequeno banco dinamarquês Lan \& Spar introduziu um serviço direto de baixo custo (telefone ou fax) para atrair clientes sensíveis a preço. 0 banco direto foi criado para competir diretamente com a rede bancária existente ao oferecer empréstimos a juros baixos aos consumidores que interagissem com 0 banco por telefone. Em 1997, o Banco Lan \& Spar evo- luiu para o primeiro banco em tempo real do mundo, atendendo a seus clientes por meio da rede bancária, da Internet e do telefone. Ao mesmo tempo em que lidar com três diferentes conceitos trouxe dificuldades, o banco foi bemsucedido em triplicar sua participação de mercado em dez anos, sendo hoje um dos mais rentáveis bancos da Dinamarca. Esse sucesso contrasta novamente com as tentativas malsucedidas de diversos bancos que desenvolveram serviços de Internet nesses últimos dez anos. Bancos proeminentes, como o NatWest, no Reino Unido, e o Bank One, nos Estados Unidos, encontraram dificuldades em operar suas atuais redes bancárias ao mesmo tempo em que atendiam seus clientes pela Internet.

0 que explica os diferentes destinos dessas companhias em competir com estratégias duplas? Por exemplo, por que grande parte das companhias aéreas no mundo considera quase impossível competir no segmento do mercado de linhas aéreas enquanto a Singapore Airlines fez com que esse mesmo desafio se tornasse al go tão fácil? Por que muitas companhias do mercado de bens de consumo massivo (fast-moving consumer goods) (FMCG), como a Unilever e a Procter \& Gamble, consideram tão difícil competir com os concorrentes de baixo custo e de private-label ao passo que outras companhias (como a SMH , a Gap e a VW) são bemsucedidas em competir, ao mesmo tempo, com estratégias de diferenciação e de baixo custo?

Nosso objetivo neste artigo é responder a essa pergunta. De acordo com Michael Porter, ${ }^{1}$ o desafio de gerenciar dois modelos de negócio no mesmo mercado é que os dois modelos (e suas cadeias de valor subjacentes) poderiam entrar em conflito um com o outro. Por exemplo, ao vender seus tíquetes pela Internet, exatamente da mesma forma que seus concorrentes, a British Airlines corre o risco de al ienar seus atuais distribuidores (as agências de viagem). De forma similar, se a Unilever entra agressivamente no mercado de private label, ela arrisca prejudicar suas marcas existentes e diluir a forte cultura da organização de inovação e diferenciação. A existência desses trade-offs e conflitos significa que uma companhia tentando competir em ambas as posições simultaneamente corre o risco de ter de pagar um enorme custo e degradar 0 valor de suas atividades existentes. 
A solução primária a que se tem chegado para resolver esse problema é manter os dois modelos de negócio (e suas cadeias de valor subjacentes) fisicamente separados em duas organizações diferentes. Essa éa "solução de inovação" primariamente associada com o trabal ho deClayton Christensen sobre inovação disruptiva, ${ }^{2}$ mas outros acadêmicos também advogam algo semelhante. ${ }^{3}$ Até mesmo Michael Porter tem defendido essa estratégia. Apesar de argumentar que a maioria das companhias que tentam competir com estratégias duplas provavelmente não serão bem-sucedidas, ele também propõe que "as companhias que buscam crescer por meio de uma ampliação em seu segmento podem conter melhor os riscos à estratégia criando unidades que se mantenham sozinhas, cada uma com sua própria marca e atividades sob medida". ${ }^{4}$

A lógica dessa solução é bastante clara. A presença de conflitos significa que a organização atual e seus gestores descobrirão que 0 novo modelo de negócio cresce independentemente deles. Eles terão então incentivos para restringir o modelo ou até mesmo acabar com ele. No entanto, ao manter os dois modelos de negócio separados, evita-se que os processos e a cultura atuais da companhia sufoquem o novo modelo de negócio. A nova unidade pode desenvolver sua própria cultura, processos e estratégia sem a interferência de sua empresa-mãe. Ela também pode gerenciar seu negócio sem ser sufocada pelos gestores da companhia estabelecida, que vêem ameaças de canibalização e conflitos de canal a todo momento.

Por mais sensível que esse argumento possa ser, a solução de separação não é isenta de problemas e riscos. Talvez o maior custo para se manter os dois negócios separados seja o fracasso em explorar as sinergias entre ambos. Por exemplo, um estudo recente realizado por um grupo de consultores da McKinsey descobriu que "a simples injunção para isolar um novo negócio é muito limitada. Embora os empreendimentos necessitem de espaço para se desenvolver, a separação estrita pode impedir que el es obtenham inestimáveis recursos e retirar de suas ma- trizes a vitalidade que elas podem gerar." ${ }^{\prime 5}$ De maneira similar, uma equipe de pesquisadores do MIT (Massachussetts Institute of Technology) observou que "empresas-derivadas freqüentemente permitem ações rápidas em um primeiro momento, mas depois têm dificuldades de alcançar um verdadeiro poder de permanecer no mercado. Pior ainda, ao lançar uma empresa-derivada, uma companhia freqüentemente cria condições que tornam uma integração futura muito difícil. " ${ }^{10}$ Por tais razões, diversos acadêmicos têm argumentado a favor de se manter o novo modelo de negócio integrado à organização existente. Para realizar essa difícil tarefa, as empresas necessitam desenvolver uma infra-estrutura organizacional "ambidestra". ${ }^{7}$

\section{dois model os (e suas cadeias de val or subjacentes) podem entrar em conflito um com o outro.}

Conforme demonstram diversos estudos, não há uma resposta "certa" para o problema. Se a empresa mantém os dois modelos de negócio separados, dá-se ao novo modelo uma chance de luta para sobreviver sem a interferência da matriz, mas também nega ao novo modelo ativos importantes, recursos e conhecimento que residem na matriz. Entretanto, se os dois modelos de negócio são integrados, 0 novo modelo se beneficia dos recursos e do conhecimento da matriz, mas também está sujeito a uma interferência inapropriada e a uma má-gestão por parte de sua matriz.

Quatro estratégias para gerenciar modelos duplos. Essa discussão sugere que, em vez de adotar uma ou outra perspectiva, a melhor solução seja abordar a questão de uma perspectiva contingencial. ${ }^{8}$ Especificamente, a literatura existente sugere que duas variáveischave influenciam na forma como uma empresa deve gerenciar os dois modelos de negócio simultaneamente: (1) a seriedade dos conflitos entre os dois negócios - pois isso 
determina se a estratégia de separação será especialmente benéfica ou não; e (2) a semel hança estratégica com que é percebido o novo mercado em relação ao negócio existente - pois isso determina a importância que terá a exploração de sinergias entre os dois. ${ }^{9}$ Quando inserimos essas duas dimensões em uma matriz (Figura), deparamos com quatro possíveis estratégias para competir com dois modelos diferentes de negócio. ${ }^{10}$

A separação é a estratégia preferida quando o novo mercado é não só estrategicamente diferente do negócio existente, mas também quando os dois mercados enfrentam sérios tradeoffs e conflitos. Entretanto, nenhuma separação é necessária quando o novo mercado é muito similar ao negócio existente e apresenta poucos conflitos que necessitam de gerenciamento. Nesse caso, abraçar 0 novo modelo de negócio por meio da infra-estrutura existente da empresa é uma estratégia superior.

U m cenário interessante surge quando o novo mercado é estrategicamente similar ao negócio existente, mas ambos enfrentam sérios conflitos. Em tal caso, seria meIhor separá-los por um período determinado e então lentamente fundir os dois conceitos de modo a minimizar 0 transtorno dos conflitos. O utro cenário interessante emerge quando o novo mercado é fundamentalmente diferente do negócio existente, mas quando ambos não entram em conflito de forma grave. Nesse caso, poderia ser melhor primeiro construir o novo negócio dentro da organização a fim de alavancar os ativos e a experiência recente da empresa (e aprender sobre a dinâmica do novo mercado) antes de separá-lo em uma unidade independente.
Contudo, a decisão sobre quando separar e quando manter o novo negócio interno é somente parte da solução. Conhecemos companhias que separaram o novo modelo de negócio e foram bem-sucedidas (por exemplo, a Singapore Airlines). Similarmente, há companhias que integraram o novo modelo de negócio eforam bem-sucedidas (por exemplo, a SMH), mas também há companhias que fizeram a mesma coisa e não foram bem-sucedidas (por exemplo, a HMT International). Além disso, uma vez que uma empresa tenha decidido quais dessas estratégias adotará (com base em suas próprias circunstâncias), a questão-chave que deve ser focada é a seguinte: "0 que diferencia a empresa bem-sucedida em cada quadrante?"

No apêndice deste artigo, descrevemos detal hadamente a pesquisa que realizamos para explorar essa questão. A seguir, apresentamos nossos principais achados. É importante destacar que, ainda que foquemos nossa discussão nas diferenças de desempenho dentro de cada quadrante da Figura, também encontramos diferenças de desempenho através dos quadrantes. Especificamente, por meio de análise de regressão descobrimos que, em média, quanto menores os conflitos e maiores as semelhanças entre os dois modelos de negócio, melhor o desempenho no gerenciamento de ambos. Esse fato é consistente com 0 argumento de Porter de que a perseguição de dois modelos de negócio diferentes, os quais apresentam conflitos inerentes e diferenças de mercado, é al go problemático e com probabilidade de fracasso. Contudo, há exceções a esse achado geral, e nossa discussão foca nessas exceções. N osso objetivo é compreender como essas companhias fizeram

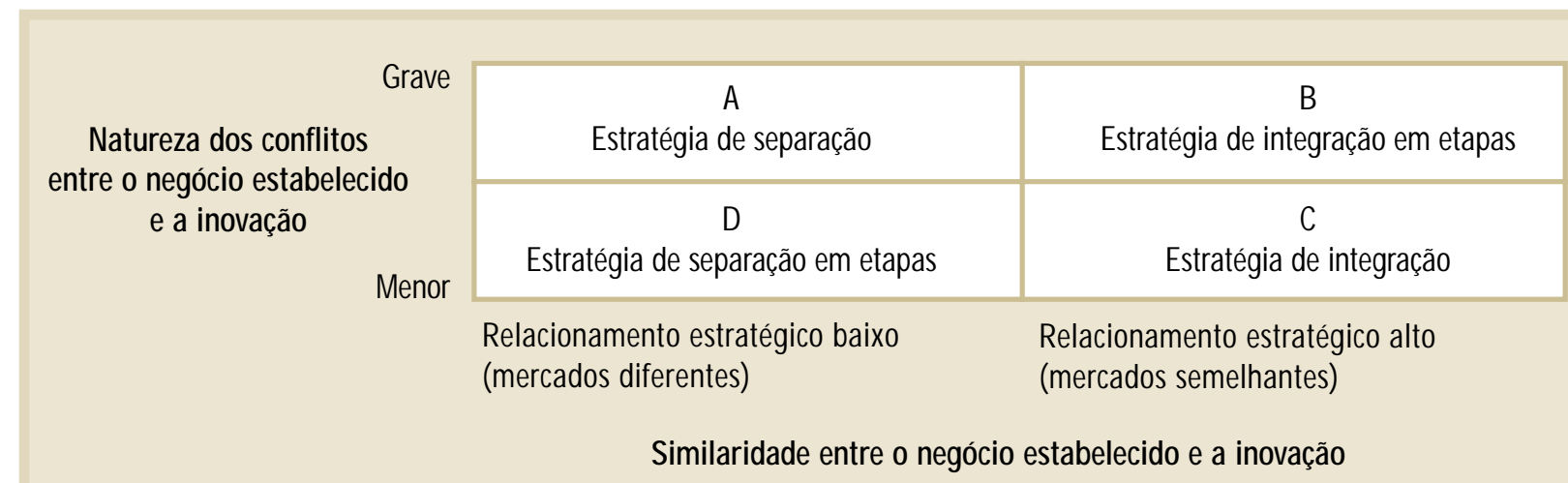

Figura: Estratégias diferentes para gerenciar modelos duplos de negócio 
para superar os tradeoffs inerentes à administração de modelos duais de negócio.

A estratégi a de separação. Quanto maiores os conflitos entre os dois model os de negócio e menor a possibilidade de que ambos os modelos possam partilhar quaisquer sinergias recíprocas, mais apropriada se torna a estratégia de separação.

N estlé e Nespresso. Essa é a estratégia que a Nestlé decidiu adotar quando criou uma unidade separada chamada Nespresso que vendia café expresso para jovens profissionais urbanos no começo dos anos de 1990. Embora o novo negócio envolvesse a venda de café, algo de que a N estlé é um dos líderes de mercado, a alta administração da empresa percebeu cedo que as similaridades entre os dois negócios eram mais ilusórias do que reais. Enquanto a N estlé estava vendendo café instantâneo (N escafé) para 0 mercado de massa, a N espresso focou especificamente nos profissionais ricos e urbanos, posicionando-se como uma marca superior. Enquanto a N estlé vendia N escafé em supermercados, a N espresso escolheu um clube exclusivo para atuar como seu distribuidor. $\mathrm{E}$ enquanto a $\mathrm{N}$ estlé seguia um modelo de negócio típico do mercado de consumo massivo (FMCG), a N esspresso adotou um modelo de negócio mais semel hante ao de uma fabricante de mercadorias de luxo.

Os dois modelos não eram somente diferentes, mas também estavam em conflito um com o outro. A N espresso estava, na verdade, canibalizando as vendas do N escafé, e os valores e atitudes da organização N espresso eram exatamente 0 oposto dos da organização tradicional Nestlé. Por essas razões, a Nestlé criou uma nova unidade em uma cidade totalmente diferente da Suíça, nomeando uma de suas estrelas nascentes como CEO, dando-Ihe liberdade e autonomia para competir em seu mercado como melhor Ihe conviesse. A estratégia mostrou-se um grande sucesso, e a N espresso é hoje uma das mais rentáveis unidades da Nestlé.

HSBC Midlands e o First Direct. O HSBC Midlands, no Reino Unido, adotou uma estratégia similar quando criou o First Direct no final dos anos de 1980 - um dos mais bem-sucedidos bancos diretos da Europa (por telefone). De acordo com Graham Picken, a quem se confiou a missão de desenvolver o First Direct, a decisão foi tomada a fim de manter a nova unidade separada o máximo possível do banco objetivando minimizar conflitos e impedir que os processos e a cultura da matriz sufocassem o novo model o de negócio. Picken afirmou:

\begin{abstract}
A questão não é se existem conflitos entre o negócio tradicional de banco de varejo e o banco direto. Eles existiam e eram importantes. A questão-chave é o quanto a companhia consegue gerenciar esses conflitos, o que, em último caso, determina seu sucesso em competir nos dois diferentes negócios. N osso banco (HSBM Midland Bank) decidiu criar o First Direct como uma companhia isolada e dar-Ihe liberdade para desenvolver seus próprios processos, estrutura organizacional, mecanismos de incentivo e controle, e para criar sua própria cultura... Sentimos que dar total autonomia à nova unidade foi mais importante do que tentar dividir recursos ou vendas aos clientes... Esse é um arranjo que funcionou para nós - não significa que funcionará para os outros.
\end{abstract}

Sinergias potenciais. Simplesmente separar o novo modelo de negócio da matriz não é suficiente para garantir o sucesso. M esmo quando a separação era a estratégia preferida, as empresas bem-sucedidas que estudamos não abandonaram as sinergias como um todo. Apesar de decidir que os dois negócios eram estrategicamente diferentes e que havia pouco escopo para explorar sinergias, as companhias bem-sucedidas instituíram processos e mecanismos para explorar quaisquer sinergias caso elas surgissem. Obviamente, o potencial para sinergias variou por companhia (dependendo de quanto os mercados eram estrategicamente similares). Isso significa que o nível de integração necessária variou dependendo da companhia. Como conseqüência, diferentes companhias instituíram diferentes níveis de mecanismos de integração. No entanto, o importante é observar que as companhias bem-sucedidas descobriram formas de explorar sinergias, não importando quão pequenas ou limitadas elas fossem. 
Esse achado é consistente com o trabal ho de Lawrence e Lorsch sobre como as companhias alcançam integração e diferenciação simultaneamente. ${ }^{11}$ Em seu estudo seminal, eles descobriram que, comparadas às companhias malsucedidas, as bem-sucedidas eram capazes de alcançar elevados níveis de integração e diferenciação. Eles também descobriram que o nível de diferenciação necessário em cada empresa dependia do ambiente externo enfrentado pela empresa (isto é, ambientes dinâmicos requerem maior diferenciação). Isso significa que as empresas que operam em ambientes dinâmicos têm de ser altamente diferenciadas, uma condição que tornaria mais difícil a manutenção do estado de integração necessário. Entretanto, empresas operando em ambientes estáveis poderiam alcançar o nível apropriado de integração mais facilmente. Isso tudo significa que as empresas bem-sucedidas usaram uma combinação diferente de mecanismos para alcançar integração: as empresas em ambientes dinâmicos usaram mais mecanismos de integração (e mecanismos mais elaborados) do que as empresas em ambientes estáveis. No entanto, ambos os conjuntos de empresas usaram mecanis- mos de integração, não importando quão pequena era a necessidade de integração.

Determi nantes do sucesso. Isso é exatamente o que encontramos em nosso estudo. Para ilustrar o que queremos dizer, considere as 42 empresas de nossa amostra que separaram o novo modelo de negócio em uma unidade independente. Delas, 10 eram classificadas como bem-sucedidas e 32 não. Usando essa amostra, realizamos múltiplas análises de regressão para identificar os determinantes de sucesso. Encontramos os seguintes resultados:

- em média, quanto maior o grau de autonomia dado pelas matrizes à nova unidade para tomar decisões financeiras e operacionais, mais eficiente foi a empresa em sua resposta;

- em média, quanto mais diferenciada eram as políticas de orçamento e investimento da nova unidade em rel ação à matriz, mais eficiente era a empresa em sua resposta. Entretanto, as empresas eram (em média) menos eficientes em competir nas duas posições estratégicas quan-

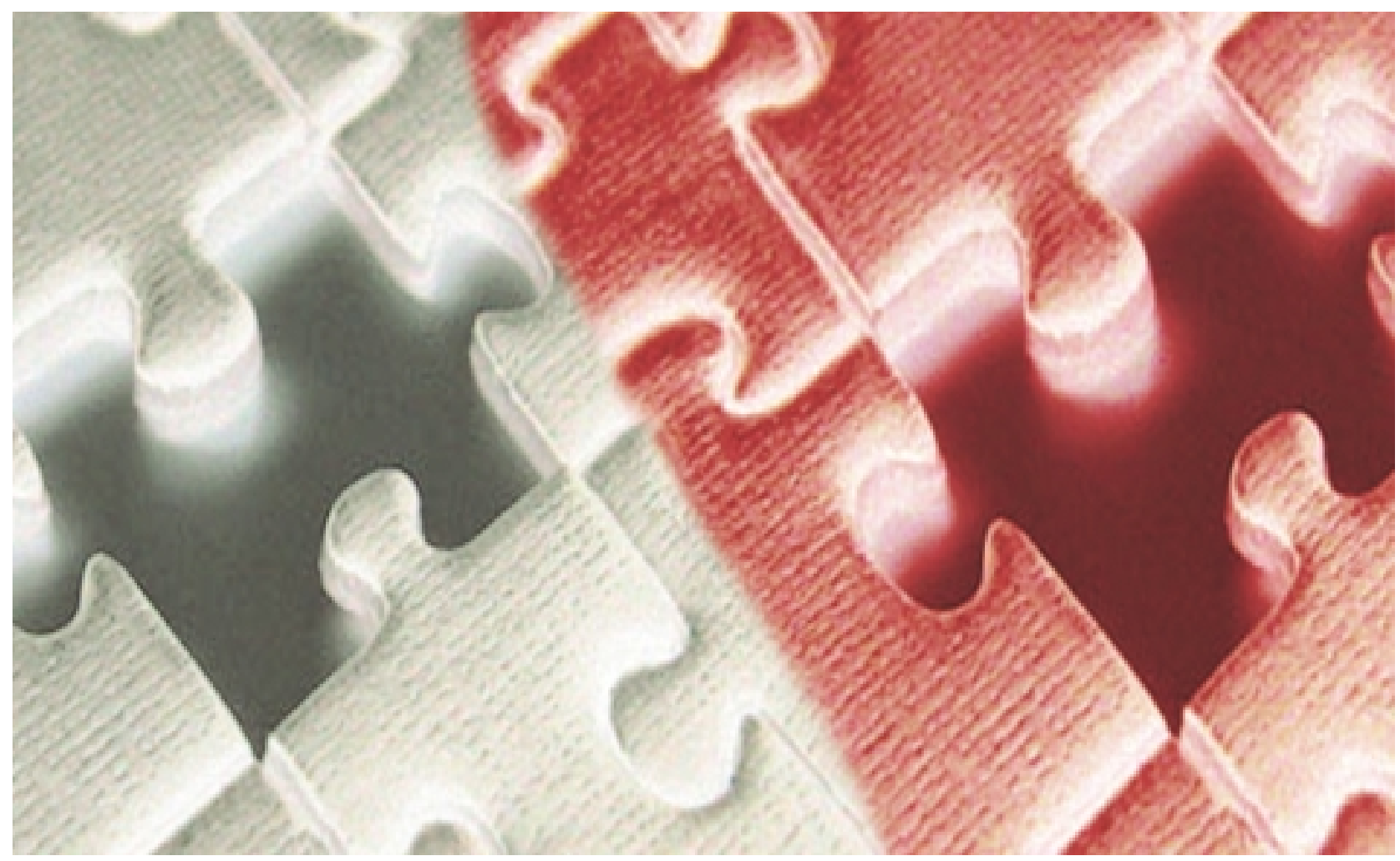


do adotavam diferentes sistemas de avaliação e incentivo na mesma unidade (em comparação com o negócio estabelecido);

- em média, empresas que el egeram um membro interno para ser o CEO da nova unidade foram mais eficientes em sua resposta do que as empresas que não o fizeram.

0 que esses resultados sugerem éque empresas bem-sucedidas dão muito mais autonomia operacional e financeira a suas unidades do que as empresas que não são bem-sucedidas. Elas também permitem que as unidades desenvolvam suas próprias culturas e sistemas orçamentários e tenham seus próprios CEOs. Essas políticas são todas consistentes com a noção de que as novas unidades necessitam de liberdade para operar como acharem melhor em seu próprio ambiente. Observe, contudo, que essa autonomia não ocorre às expensas de sinergias. A matriz continuará a observar atentamente a estratégia da unidade, e a cooperação entre a unidade e a matriz será encorajada por meio de sistemas de incentivo e recompensa. Além disso, os CEO s das unidades foram transferidos de dentro da organização a fim de facilitar uma cooperação mais estreita e uma exploração ativa de sinergias.

Resultados de pesquisa sugerem fortes evidências para nossa pesquisa de campo. Por exemplo, um executivo sênior de uma das maiores empresas de suprimentos de escritório dos Estados Unidos confirma isso pela passagem abaixo:

Recuso-me a ter uma $P \& L$ para uma operação ponto.com e uma diferente $P \& L$ para o negócio principal. Isso apenas criaria atritos e disputas. Todos os VPs são avaliados por nossas vendas consolidadas, e não pelas vendas da matriz versus da unidade. $N$ ão importa qual método o consumidor usa para fazer um pedido (telefone, Internet, loja), o vendedor responsável pela região terá seu crédito.

Similarmente, o diretor de estratégia de uma das maiores companhias aéreas da Europa sugeriu o seguinte:

$N$ ão faz absolutamente nenhum sentido criar uma subsidiária de baixo custo e não Ihe dar liberdade para decidir o que fazer em seu mercado. Mas éigualmente tolo ignorar que estamos no negócio de linhas aéreas há mais de meio século. 0 bviamente nossa subsidiária pode aprender alguma coisa conosco!

N ossos resultados explicam por que argumentamos anteriormente que a separação não é nem necessária nem suficiente para garantir o sucesso. Mesmo que uma empresa decida separar-se do novo modelo de negócio, ela deve ainda encontrar formas de explorar suas forças existentes (como sua marca, recursos financeiros e a experiência no segmento) na nova unidade. N esse sentido, a pergunta que deve ser feita não é "Devemos separar ou não?", mas "Q uais atividades, em nossa cadeia de valor, devemos separar e quais atividades devemos manter integradas?"12

A estratégia de integração. Freqüentemente, o novo modelo de negócio apresenta poucos conflitos com aquele modelo já existente de uma empresa. Por exemplo, a Internet e a distribuição de computadores on-line eram certamente um desafio para a Dell, mas o novo modo de vender computadores não era particularmente ${ }^{13}$ nocivo em relação ao modelo de negócio existente na empresa. N esses casos, abraçar o novo model o por meio da infra-estrutura existente da empresa pode ser a estratégia ótima. Principalmente quando, além da ausência de conflitos, os dois modelos atendem a negócios estrategicamente similares e assim obtêm ganhos em explorar as sinergias recíprocas.

Edward Jones. Considere o exemplo da Edward Jones, uma das empresas-líderes no setor de corretagem de varejo nos Estados Unidos. A empresa decidiu acertadamente desde o início que não responderia ao investimento on-line criando uma unidade separada. De acordo com o atual sócio-gerente da empresa, Doug Hill, “Decidimos não imitar a massa. Pensamos que o investimento on-line é para especuladores e entretenimento. Não estamos no negócio de entretenimento. Estamos no mercado da "segurança de espírito".

Como, então, a Edward Jones está respondendo à ameaça on-line? Focando conscientemente em seu modelo estabelecido de negócio e usando a Internet como uma oportunidade para aumentar sua proposta existente de valor para seus clientes-alvo. Significa considerar a Inter- 
net simplesmente como um outro canal de distribuição e usá-la para oferecer melhores serviços e mais informações para os clientes. A proposição de valor da Jones envolve negociações face a face e pessoais com os clientes a fim de oferecer-Ihes mecanismos de investimento de longo prazo e conservadores. Como conseqüência, a Internet é usada não para investimento on-line, mas como um meio para aprimorar o relacionamento com o cliente. Como o exCEO John Bachmann reiterou em recente artigo na revista Fortune: "Vocênão comprará ações pela I nternet na Edward Jones. Isso está se tornando verdade na medida em que vejo adiante, no futuro... Se você não está interessado em um relacionamento e apenas quer uma transação, então você deveria ir até 0 e-trade se quer encontrar um bom preço. Nós simplesmente não estamos nesse negócio."14

\section{Decidir quando separar e quando manter o novo}

\section{negócio interno é somente parte da sol ução.}

Outro exemplo: Merrill Lynch. A Merrill Lynch é outra empresa que respondeu às transações on-line com uma estratégia integrada. A empresa lançou um canal de transação on-line dentro do negócio tradicional e ajustou seus processos e incentivos para que o negócio on-line pudesse coexistir sem descontinuidades com o negócio existente. A empresa desenvolveu dois novos produtos o Unlimited Advantage e o M errill Lynch Direct - , ambos integrados às operações existentes da empresa e à infra-estrutura de TI. Os produtos on-line foram integrados aos produtos existentes da empresa a fim de que os clientes - os antigos e os novos - pudessem escoIher, a partir de um menu, qual nível de conselho precisavam e qual tipo de transação gostariam de realizar. A política de compensação da empresa foi então ajustada a fim de que os corretores fossem compensados pelo valor do total de ativos por eles gerenciados, sem importar como tais ativos eram adquiridos (isto é, por via on-line ou pela rede convencional).

Enquadramento de oportuni dades. Da mesma forma que a estratégia de separação descrita anteriormente, descobrimos que simplesmente integrar o novo modo de competição à infra-estrutura existente não é suficiente para garantir o sucesso. As empresas mais bem-sucedidas em nossa amostra eram aquelas que não apenas integravam 0 novo modelo de negócio (alavancando, dessa forma, as competências de negócio e conhecimentos existentes), mas que também tratavam o novo modo de competir como uma maravilhosa nova oportunidade para fazer crescer o negócio. Como conseqüência, elas garantiram que as forças do negócio tradicional fossem alavancadas, mas também tomaram extremo cuidado para não se sufocar no novo negócio com as políticas existentes da empresa. Um bom exemplo disso éa decisão da M errill Lynch descrita anteriormente de mudar seus sistemas de investimento a fim de que seus corretores tivessem um incentivo para apoiar o sistema de transação on-line.

A decisão bem-sucedida das empresas em proteger o novo modo de competir das políticas e mentalidade das empresas existentes baseou-se em sua crença de que o novo modo era mais uma oportunidade do que uma ameaça. Isso é importante porque, conforme a teoria da categorização, enquadrar um desenvolvimento externo como uma oportunidade resulta em maior envolvimento no processo de resolvê-lo, bem como maior participação dos níveis mais baixos da organização, e age diretamente sobre a mudança do ambiente externo. ${ }^{15}$ Clark Gilbert e Joe Bower fazem uma colocação semelhante. ${ }^{16}$ Eles argumentam que, quando uma organização primeiro se confronta com um modelo conflitante de negócio, é melhor considerar isso como uma ameaça do que como uma oportunidade. Enquadrá-la como uma ameaça provocará um forte comprometimento na organização a fim de responder à ameaça de forma agressiva. Contudo, quando a organização está pronta para realmente criar um novo modelo de negócio a fim de explorar o novo mercado, então é melhor considerá-lo uma oportunidade. Desse modo, velhos modelos e pressuposições serão deixados de lado, e o novo modelo será avaliado por seus próprios méritos. De acordo com Gilbert e Bower, o reconhecimento da necessidade de gerenciar modelos concorrentes simultaneamente é a chave para uma resposta eficiente. 
Considerar o novo modelo uma oportunidade influenciou as ações das empresas de duas formas: (a) no modo como elas o abordam; e (b) o que elas realmente fazem para tirar vantagem dele.

Considere, por exemplo, as seguintes citações de executivos seniores de duas empresas norte-americanas. 0 primeiro é VP de uma das maiores empresas fornecedoras de materiais de escritório, que foi classificada como muito bem-sucedida ao adotar a distribuição pela Internet:

Entramos na Internet antes que todo mundo soubesse o que era a Internet. Na verdade, nosso maior problema pelos primeiros dois anos foi persuadir nossos clientes a usá-la! Mas persistimos porque eu sabia 0 que era a Internet. Essa nova tecnologia iria se tornar o futuro. Ela seria o meio de nos permitir fazer grandes coisas novas.

A segunda citação é do CEO de uma das maiores vendedoras de livros que foi classificada como malsucedida na adoção da distribuição on-line de livros:

Fomos os últimos a implementá-la, mas não em avaliála. Nossa avaliação foi de que ela não fazia sentido. Contudo, toda vez que eu tentava explicar nossas razões pelas quais não faríamos isso para Wall Street, 0 preço de minhas ações caía! Mesmo em 1997, quando a distribuição on-line de livros foi de $0 \%$ a $6 \%$, as grandes lojas aumentaram sua participação de 10\% para $20 \%$ - no entanto, nosso preço de estoque despencou para $40 \%$. Assim, no final, decidimos que tínhamos de fazer algo.

Por que o enquadramento da decisão como uma oportunidade é tão importante? A razão por nós dada é que, ao considerá-la como uma oportunidade, a empresa aborda o desafio de uma maneira pró-ativa, estratégica, em vez de uma reação apressada, do tipo reflexo, ao problema. 0 novo mercado é avaliado de um modo consciente e deliberado, e os recursos necessários são alocados a fim de explorar e fazer crescer as oportunidades. Ainda mais importante, os gestores mais respeitados na organização são indicados para a missão, e o projeto recebe um eleva- do nível de atenção e cuidado. Finalmente, visualizar a decisão como uma oportunidade encoraja a empresa a desenvolver uma visão de longo prazo do investimento, o que garante os recursos e o comprometimento de longo prazo mesmo quando os resultados iniciais não são encorajadores.

No entanto, a principal razão pela qual é importante ver o novo modo de competir como uma oportunidade é que isso permite aos gestores colocar os velhos modelos e pressuposições de lado e abordar a oportunidade de modo criativo e empreendedor, o que, por sua vez, Ihes permite colocar em andamento estratégias que não apenas tiram vantagem da oportunidade mas que também coloquem na defensiva as próprias empresas que introduziram os novos modelos no setor. Em um certo sentido, as empresas estabelecidas encontram maneiras de atacar seus agressores.

Para entender como elas fazem isso, é importante lembrar que, freqüentemente, os novos modelos de negócio criam mercados que têm margens muito menores do que os mercados tradicionais. Isso sugere que, mesmo no meIhor cenário, quando a empresa estabelecida é bem-sucedida em abraçar o novo modelo, o resultado final será a canibalização das vendas existentes e margens ainda menores! Considere, por exemplo, o seguinte comentário do VP de uma das maiores empresas do setor de bens de consumo massivo:

A questão não ése podemos responder à ameaça do mercado customizado (privatelabel) de maneira bem-sucedida. Acredito que podemos fazêlo, internamente ou com uma unidade separada. Mas qual é o propósito de fazer isso se o resultado final é destruir o setor? Eu não quero jogar o jogo deles. 0 que precisamos fazer é encontrar uma resposta que se baseie em nossas próprias competências e que restaure as margens desse negócio.

A lógica desse argumento é ecoada em outro comentário feito por um executivo da SMH para nos explicar a razão existente por trás do desenvolvimento da Swatch no começo dos anos de 1980:

Tínhamos de defender a parte pobre do mercado contra os relógios baratos japoneses. Mas não queríamos 
simplesmente competir em preços... Tínhamos de encontrar um modo de produzir al guma coisa que fosse barata 0 bastante (ênfase acrescentada), mas que ainda tivesse a qualidade Swiss.

Ambos os comentários apontam para o que acreditamos ser a chave para o sucesso das empresas que escolhem a estratégia de integração: abraçar o novo modelo de negócio de uma forma criativa que tome como base as competências dos concorrentes estabelecidos e restabeleça as margens do negócio em um nível mais elevado do que as empresas concorrentes têm feito. Nesse processo, as empresas estabelecidas contra-atacam seus próprios agressores.

SMH e Swatch. Considere, por exemplo, a história da SMH novamente. No começo dos anos de 1960, a Swiss dominava a indústria global de relógios. Esse domínio, no entanto, evaporou nos anos de 1970, quando empresas como Seiko (do Japão) eTimex (dos Estados Unidos) introduziram relógios baratos que utilizavam a tecnologia quartz e ofereciam funcionalidade e características agregadas (como função de alarme, indicação de data etc.). A participação daSwiss na produção mundial declinou de 48\%, em 1965, para $15 \%$ em 1980. Em resposta, a Swiss introduziu 0 Swatch. 0 novo relógio não apenas introduzia estilo como uma dimensão competitiva, mas também, e mais importante, era vendido a um preço em média três vezes mais caro do que a média de preço da Seiko. Desde seu lançamento, em 1983, a Swatch tornou-se o mais popular modelo de relógio, com mais de 100 milhões vendidos em mais de 30 países.

0 segredo desse sucesso está em duas áreas. Primeiro, observe que os concorrentes estabelecidos (a Swiss) estavam vendendo seu produto na base de desempenho quando, de repente, se viram atacados. 0 ataque tomou a forma de "Nossos relógios são bons o suficiente em desempenho e são superiores aos da Swiss em preço". 0 que a Swiss fez foi traduzir essa lógica à sua própria maneira. Eles vendiam seus Swatch de acordo com a seguinte premissa: "N ossos relógios são bons o suficiente em preço e superiores aos japoneses em desempenho (isto é, estilo)". Essa afirmação soa bem, mas requer uma mudança fundamental (ou revolucionária?) de mentalidade! Em vez de adotar a mentalidade dos atacantes, que dizia "Minimize o preço sujeito a um desempenho bom o suficiente", a nova mentalidade necessária dizia "M aximize o desempenho sujeito a um preço bom o suficiente".

Segundo, uma coisa é dizer isso; outra coisa é fazê-lo. De fato, o que a Swiss fez foi produzir al go que entregava baixo custo e diferenciação ao mesmo tempo - gerenciando duas estratégias conflitantes ao mesmo tempo. Eles atingiram esse fim eliminando muitos atributos dos produtos que julgavam ser desnecessários (dessa forma, cortando custos), ao mesmo tempo aprimorando outras características dele, como estilo e desenho (criando, dessa forma, diferenciação). Eles também encontraram formas de cortar outros custos (na manufatura e nos materiais usados) e de criar novas formas de diferenciação (por exemplo, por meio do Swatch Club). 0 resultado final foi uma estratégia que aprimorou as características-chave do novo modelo de negócio a partir de um modelo tão criativo que seus atacantes originais tiveram de encontrar suas próprias respostas ao contra-ataque da Swiss!

G illette. O utro exemplo da mesma estratégia é a resposta da Gillette à ameaça da lâmina descartável em seu negócio. Os descartáveis entraram no mercado de lâminas com a seguinte premissa: "N ossos produtos são bons o bastante em desempenho e superiores aos da Gill ette em preço". Qual foi a resposta da Gillette a essa ameaça? Fazer elaborações partir da premissa de que "N ossos descartáveis são bons o suficiente em preço e superiores aos outros descartáveis em desempenho".

Em vez de discutir a produção de um descartável mais barato ou não, a Gillette escolheu enfrentar a ameaça de maneira criativa. Ao adotar a mentalidade "Precisamos maximizar o desempenho sujeito a um preço que seja bom o suficiente", el es desenvolveram vários produtos descartáveis inovadores que concorreram não apenas em preço, mas também em desempenho. Por exemplo, em 1994 eles introduziram o Custom Plus, uma linha de descartáveis com fita lubrificante. No final de 2002, introduziram uma nova linha de lâminas descartáveis com tecnologia proprietária. Ao adotar estratégias de baixo custo e diferenciação de forma bem-sucedida, a Gillette tem conseguido manter uma participação de $45 \%$ do mercado de lâminas descartáveis. 
A lição dessas histórias de sucesso é simples: é possível gerenciar duas estratégias conflitantes sem mantê-las separadas. Mas fazê-lo requer criatividadee disposição em ir além de simplesmente imitar um novo modelo de negócio. Ao focar apenas em encontrar modos de acomodar um novo modelo a fim de minimizar potenciais conflitos, as empresas estabelecidas podem perder a oportunidade de explorar o novo modelo de forma a alavancar suas competências únicas e restabelecer seus mercados em níveis mais elevados de rentabilidade.

É importante destacar que uma coisa é dizer que empresas como a Swatch e a Gillette ad otaram uma estratégia de baixo custo e diferenciação; outra é sugerir que elas foram as melhores diferenciadoras e líderes de custo ao mesmo tempo! 0 ponto-chave a ser lembrado aqui é que a Swatch e a Gillette assentaram-se em sua base de vantagem competitiva (diferenciação) mas encontraram um modo de fazer isso melhor (a um custo mais baixo). Elas não adotaram uma estratégia de líder de custo, que se baseia em habilidades de processos de fabricação, e, por essa razão, escolheram não competir diretamente com seus atacantes (onde não teriam dúvidas de que perderiam). Em vez disso, elas elaboraram sua nova estratégia em habilidades únicas de desenho e marketing, jogando de modo diferente daquele de seus atacantes.

A estratégia de integração em etapas. Sob certas circunstâncias, a estratégia mais apropriada é separar ou integrar o novo modo de competir, mas não no começo. Por exemplo, quando o novo modelo de negócio atende a um mercado que é estrategicamente similar ao negócio existente, mas as duas formas de competição enfrentam sérios conflitos mútuos, a empresa enfrenta um difícil desafio: por um lado, ela se beneficia se integrar os dois e explorar as sinergias entre eles; por outro, a integração poderia levar a sérios problemas internos em virtude de todos os conflitos. N esse caso, seria mel hor separar os dois conceitos por um período de tempo e então lentamente fundi-los a fim de minimizar a interrupção de conflitos. Essa é uma estratégia de integração em etapas.
Lan \& Spar Bank. 0 banco dinamarquês Lan \& Spar é um bom exemplo de empresa que seguiu a estratégia de integração em etapas. Q uando ele decidiu criar um banco direto junto com sua rede convencional, manteve os dois conceitos separados por três anos antes de fundi-los em um único. O CEO Peter Schou explicou sua estratégia da seguinte forma:

\begin{abstract}
Era uma situação difícil para ter dois conceitos ao mesmo tempo. Não podíamos realmente sustentar a fusão dos dois conceitos logo no começo porque não tínhamos sofrido um custo de canibalização sério. Nossa margem de lucro na rede era de $10 \%$ por ano, ao passo que no Direct Bank era de apenas 3\% ao ano. Se tivéssemos permitido que todos os nossos clientes migrassem do banco tradicional para o banco direto, teríamos perdido muito dinheiro. Tínhamos de gerenciar a transição cuidadosamente.
\end{abstract}

Como no caso da estratégia de separação descrita anteriormente, o desafio que a empresa enfrenta na estratégia de integração por etapas é manter o novo modelo de negócio protegido da mentalidade e das políticas do negócio existente e, ao mesmo tempo, tentar explorar as sinergias entre os dois negócios. No entanto, há uma complicação adicional: a empresa sabe que a separação é apenas temporária e que a nova unidade terá de ser integrada mais cedo ou mais tarde à organização existente. 0 desafio é manter a nova unidade separada, mas também prepará-la para um eventual casamento.

\section{Si mpl esmente separar o novo} modelo de negócio da matriz não é suficiente para garantir o sucesso.

\footnotetext{
As empresas podem usar várias táticas para alcançar esse propósito. Por exemplo, o Lan \& Spar separou o Direct Bank do resto da organização, mas garantiu que a infraestrutura de $\mathrm{TI}$ que dava suporte ao banco por telefone fosse compatível com o sistema de TI do banco estabele-
} 


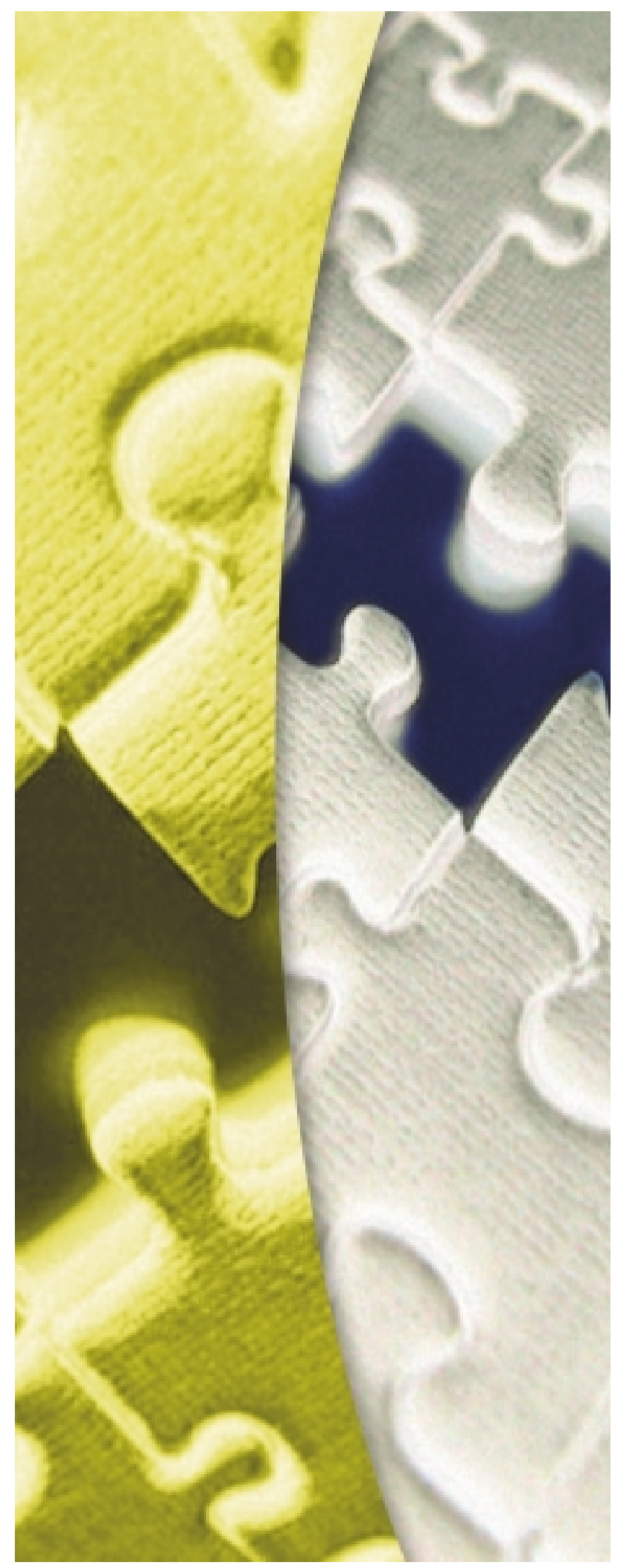

cido. Além disso, o banco garantiu que os empregados desenvolvessem valores comuns e uma cultura comum insistindo que os empregados de ambas as partes da organização se encontrassem regularmente, participassem dos mesmos eventos promovidos pela empresa e tivessem experiências semel hantes com os executivos seniores do banco. Os executivos do banco principal foram transferidos para o Direct Bank, e as decisões sobre como fundir os dois bancos foram tomadas em reuniões entre os executivos de ambas as unidades. Os dois conceitos foram finalmente fundidos três anos depois da criação do Direct Bank, e todos os indicadores financeiros sugerem que a fusão foi um grande sucesso.

Charles Schwab e e.Schwab. Outra empresa que seguiu a estratégia de integração em etapas foi a Charles Schwab. Ela tinha criado originalmente a e.Schwab, seu negócio de corretagem on-line, como uma unidade separada. No entanto, preparou a e.Schwab para uma integração eventual tendo a colocado em reporte direto ao co-CEO David Pottruck e a munido com uma equipe de executivos da organização de varejo já existente. Além disso, a plataforma tecnológica da e.Schwab foi desenhada para integrar-se com o sistema de TI da Schwabs, e as novas políticas de produção e preço da unidade foram desenhadas para serem compatíveis com as políticas da matriz. A inevitável fusão dos dois conceitos foi novamente considerada um grande sucesso.

A estratégia de separação em etapas. Quando os dois modelos de negócio não conflitam entre si gravemente, mas quando os mercados a que eles atendem são fundamentalmente diferentes, então a empresa enfrenta outro desafio interessante. Por um lado, tendo em vista a ausência de conflitos, a empresa poderia integrar o novo modelo com a organização existente sem grande dificuldade. Por outro lado, a integração não traz muitos benefícios e poderia até mesmo restringir o desenvolvimento do novo modo de competir em um negócio viável para a empresa. Nesse caso, seria melhor primeiro construir 0 novo negócio dentro da organização a fim de alavancar os ativos e as experiências existentes da empresa antes de separá-la em uma unidade independente. Essa é a estratégia de separação em etapas. 
Preparar uma unidade para o casamento é o desafio das empresas que escolhem a estratégia de integração em etapas. Em comparação, o desafio que enfrentam as empresas que escolhem a estratégia de separação é o de preparar uma unidade para o divórcio.

Tesco e Tesco.com. Essa é exatamente a forma como a Tesco, a maior e mais famosa rede de supermercados do Reino Unido, está abordando seu braço de distribuição on-line, a Tesco.com. 0 serviço de entrega domiciliar da empresa foi iniciado no meio dos anos de 1990 sob o nome de Tesco Direct. As primeiras operações envolveram uma loja no oeste de Londres que enviava pequenas entregas para aposentados impossibilitados de ir até a loja. A idéia de fazer compras em casa foi desenvolvida ao longo dos anos, primeiro com clientes fazendo pedidos a partir de um catálogo impresso, depois por meio de um CD-ROM e, finalmente, pelo website da empresa. Em 2000, o braço virtual da Tesco estava coletando 10 mil pedidos por semana, a maioria na área da grande Londres. Em 2003, os pedidos chegavam a 110 mil por semana, e o serviço de entrega doméstica cobria a maior parte de todas as lojas ao redor de todo o Reino Unido.

Com o passar do tempo, o negócio de distribuição on-line ganhou vida própria. De acordo com N ick Lansley, o executivo de TC da Tesco:

Começamos oferecendo uma limitada variedade de itens de mercearia, mas no verão de 1996 nos perguntamos por que não poderíamos vender cada item em uma loja virtual da Tesco. Por que não livros, roupas e itens eletrônicos? Poderíamos começar adicionando um grupo de produtos a outro ou colocando todos eles juntos. Era um grande salto, mas sentimos que era agora ou nunca. Não estávamos preocupados com os concorrentes. Somente a Sainsbury era um possível rival, e eles não estavam fazendo nada do que conhecíamos. Mas estávamos preocupados sobre como fazê-lo. Ir até o board da empresa e pedir miIhões de libras para construir depósitos dedicados e sistemas de logística? Analisamos outros model os que já haviam sido desenvolvidos internamente nas Iojas da Tesco.
Em 2001, a Tesco Direct estava reorganizada como uma filial plena da Tesco e foi renomeada como Tesco.com o primeiro passo nos procedimentos de divórcio. 0 braço on-line red efiniu sua missão de uma distribuição online de mercearias para um revendedor on-line de todo tipo de produto (livros, CDs, outros itens não-alimentícios), e executivos seniores foram contratados para conduzir o novo negócio rumo ao futuro. Em 2003, o board da Tesco disse aos executivos da Tesco.com que, se tudo corresse bem, eles planejavam separar a unidade como uma empresa limitada. 0 braço on-line era agora um negócio tão diferente que fazia pouco sentido mantê-lo sob a direção da Tesco. Haviam sido dadas liberdade e autonomia para que ela pudesse encontrar seu caminho.

De acordo com um analista, a evolução da Tesco.com para um negócio separado foi compreensível:

O mundo virtual é visto como um complemento, e não como um concorrente da experiência não virtual. 0 negócio on-line está permitindo que a Tesco expanda para bens diversificados, como CDs e livros, e está provocando um crescimento adicional. Essa diversificação está caminhando de maneira ad hoc. Há, obviamente, pequenas dificuldades pelo caminho com esse desenvolvimento. Comprar música ou livros on-linena Tesco.com éuma experiência muito pobrequenão está integrada com o negócio central queé a mercearia. Eles parecem estar fazendo uma experiência na perspectiva do público. Por que eles estão fazendo isso? Alimentos on-line não propiciam boas margens para que eles expandam para áreas com maiores margens. 0 que é crucial para eles éo comportamento do consumidor eles preferem comprar esses itens em sites dedicados (exemplo, Amazon) ou em um que forneça produtos e serviços integrados (por exemplo, a Tesco.com)? Eles estão usando fornecedores terceirizados para esses produtos (que agora incluem tel efones celulares e serviços bancários) como uma forma de minimizar riscos de inventário. Eles não têm vencido as dificuldades de sua estratégia de "ir ao mercado". Esse é um grande desafio para eles. Os clientes desejam uma experiência de compra sem reparos. 
Da mesma forma que com a estratégia de integração descrita anteriormente, 0 desafio que as empresas enfrentam na estratégia de separação por etapas é manter os dois negócios para explorar quaisquer sinergias entre eles ao mesmo tempo em que mantêm o novo modelo denegócio protegido do negócio existente. No entanto, existe um desaComo o exemplo da Tesco mostra, não há uma maneira já estabelecida de fazê-lo, mas o desafio permanece: como coexistir com algo de que fatalmente se vai divorciar.

Não há um mel hor e único modo. Ao menos na literatura acadêmica tem havido desacordos sobre se, e como, uma empresa poderia gerenciar dois modelos diferentes e conflitantes de negócio ao mesmo tempo. Alguns têm argumentado que, em virtude dos conflitos entre os dois modelos de negócio, uma empresa deveria mantê-los fisicamente separados a fim de proteger o novo modelo da interferência dos executivos do negócio estabelecido. O utros têm proposto que tal solução priva os dois modelos de negócio da oportunidade de explorar sinergias entre eles. Eles têm argumentado, por essa razão, a favor de uma estratégia de integração. fio: preparar a nova unidade para inevitável separação.

novo modelo de negócio por meio da infra-estrutura organizacional da empresa existente é a estratégia superior. Também descrevemos as circunstâncias quando uma empresa deveria preferir separar (integrar) o novo modelo de negócio antes de integrá-lo com (separá-lo de) o negócio existente. Também propusemos que o melhor modo de abordar a questão é por meio da perspectiva da contingência.

Além disso, argumentamos que simplesmente separar ou integrar o novo modelo de negócio não é suficiente para garantir o sucesso. Se a estratégia preferida é a separação, a empresa deve ainda encontrar formas de explorar suas forças existentes (tais como sua marca, recursos financeiros e experiência no setor) na nova unidade sem restringi-la. Similarmente, se a estratégia preferida é a integração, a empresa deve lutar para proteger o novo modelo de negócio de uma excessiva interferência ou má gestão por parte da matriz, tudo em nome da exploração de sinergias. N esse sentido, a pergunta que deve ser feita não é "Deveríamos separar (integrar) ou não?", mas "Quais atividades, em nossa cadeia de valor, devemos separar e quais atividades devemos manter integradas?"

Assim, nosso estudo sugere que o processo de tomada de decisão que os executivos devem conduzir envolve três passos. Primeiro, a questão "Deveríamos adotar o novo modelo de negócio ou não?" deveria ser levantada. A resposta para ela depende das circunstâncias específicas de cada empre-

Neste artigo propomos que, sob certas circunstâncias, a estratégia de separação é preferível à estratégia de integração, mas, sob outras circunstâncias, a estratégia de integração poderia ser preferível à de separação. Especificamente, argumentamos que a separação éa estratégia preferível quando o novo mercado não é só estrategicamente diferente do negócio existente, mas também quando os dois modelos de negócio enfrentam graves tradeoffs e conflitos. Entretanto, nem a separação é necessária quando o novo mercado é muito similar ao negócio existente e ap resenta poucos conflitos que necessitam ser gerenciados. Nesse caso, abraçar o sa. Se a decisão de que a empresa deveria adotar o novo modelo de negócio for a escolhida, a segunda pergunta que deve ser feita é "D everíamos separar ou integrar o novo modelo de negócio ou seguir uma das estratégias em etapas?" A resposta dependerá, provavelmente, das duas variáveis críticas que identificamos anteriormente e que definem os eixos da Figura. Finalmente, uma vez que a decisão de separar/integrar seja tomada, uma outra pergunta emerge: "Tendo em vista nossa escolha, como podemos gerenciar a nova unidade de maneira bem-sucedida?" 
Nosso artigo foi focado na última pergunta e identificou diversas variáveis que podem influenciar no modo como o segundo modelo denegócio é gerenciado em cada um dos quatro quadrantes da Figura. Por exemplo, descobrimos que as empresas que adotam a estratégia de separação terão sucesso se:

- oferecerem autonomia operacional e financeira a suas unidades, mas ainda mantiverem uma estreita atenção sobre a estratégia da unidade e encorajarem a cooperação entre a unidade e a matriz por meio de incentivos e sistemas de recompensas comuns;

- permitirem que as unidades desenvolvam suas próprias culturas e sistemas orçamentários;

- permitirem que cada unidade tenha seu próprio CEO, transferido do interior da organização (em vez de contratar alguém externo).

Similarmente, descobrimos que as empresas que adotam a estratégia da integração terão sucesso se:

- tratarem o novo modelo de negócio como uma maraviIhosa nova oportunidade para desen-

volver o negócio (em vez devê-lo como uma ameaça);

- alavancarem as forças do negócio tradicional para encontrar modos de se diferenciarem (em vez de imitar as estratégias de seus adversários);

- abordarem a tarefa de uma maneira pró-ativa e estratégica, em vez de uma reação reflexa e imediata ao problema. Apesar das histórias de sucesso descritas neste artigo, nossos resultados da análise de regressão de uma ampla amostra também demonstram que perseguir simultaneamente dois modelos de negócio que apresentam conflitos inerentes e diferenças de mercado é extremamente problemático e fadado ao fracasso. Neste artigo, focamos as exceções. Empresas que estão considerando adotar um segundo modelo de negócio ou não devem manter em mente que a sorte ainda está contra elas. Mas, como nosso estudo sugere, as recompensas de uma abordagem contingencial para competir com modelos duplos de negócio podem ser grandes.

\section{Apêndice}

\section{Desenho de pesquisa e amostragem}

Nossa principal pergunta de pesquisa foi: "O que diferencia as empresas bem-sucedidas em cada quadrante da Figura?" Para respondê-la, tivemos de focar em quatro tarefas específicas: (1) identificar um número suficiente de empresas estabelecidas que tivessem adotado um segundo modelo de negócio em seu mercado; (2) mapear cada empresa em nossa matriz de dupla entrada (de acordo com os conflitos e sinergias que cada uma identificou em seu segundo modelo de negócio; (3) identificar as empresas bem-sucedidas e as malsucedidas em cada quadrante; e (4) examinar o que diferencia as empresas bem-sucedidas em cada quadrante.

Primeiro tentamos identificar uma amostra de empresas estabelecidas que tinham adotado um segundo modelo de negócio. Decidimos procurar por essas empresas em diversos setores industriais da Europa e dos Estados Unidos nos quais sabíamos que novos modelos de negócio

\section{A principal razão pela qual era importante} consi derar o novo modo de competir como uma oportunidade era que isso permitiria aos executivos colocar os vel hos model os e pressupostos de lado e abordar a oportunidade de um modo criativo e empreendedor.

estavam em curso nos últimos anos. Especificamente, examinamos as seguintes indústrias: banco, seguradoras em geral, seguradoras de vida e saúde, corretagem, supermercados, companhias aéreas, FMCGs, livrarias, fornecedores de material de escritório e sistemas de transação eletrônicos. Os novos modelos de negócio introduzidos nessas indústrias foram: banco direto (telefone ou Internet); seguros gerais diretos; seguros de vida e saúde diretos; transações de corretagem on-line; pedidos em casa e entrega de produtos de mercearia; serviços de baixo custo, 
sem adornos, das companhias aéreas; private label no setor FMCG; distribuição on-line de livros; distribuição online de suprimentos de escritório; e sistemas de transação baseados em interface el etrônica.

Entrevistamos então dez companhias estabelecidas na Europa e nos Estados Unidos. As entrevistas foram conduzidas pessoalmente (principalmente no escritório central da empresa) e levaram, em geral, de duas a quatro horas, dependendo do número de pessoas entrevistadas em cada empresa. Seguindo as entrevistas, preparamos diversos estudos de caso curtos descrevendo os vários insights que eram produzidos.

Usando as idéias desenvolvidas pelo trabal ho de campo e correntes rel evantes da literatura, preparamos então um questionário detalhado abordando nossas questões de pesquisa. Um questionário de 13 páginas específico para cada indústria foi enviado a 740 empresas estabelecidas na amostra de indústrias. Recebemos 115 questionários completos de 98 empresas diferentes.

Nosso questionário procurou quantificar as razões que levaram cada empresa estabelecida a responder à introdução de um novo modelo de negócio em seu mercado, a natureza da resposta e as estratégias usadas para gerenciar os dois modelos de negócio simultaneamente. Para os propósitos deste artigo, estávamos particularmente interessados em três itens de nosso questionário: (1) a natureza e a magnitude dos conflitos entre o modelo de negócio da empresa existente e o novo modelo de negó- cio introduzido - a fim de avaliar o nível em que a estratégia de separação entre os dois model os poderia ser benéfico; (2) como relacionar os mercados em que os dois modelos de negócio estavam tentando servir - a fim de avaliar se a exploração de sinergias entre os dois era necessária ou benéfica; e (3) o quanto a empresa foi bemsucedida em gerenciar os dois modelos de negócio ao mesmo tempo.

0 nível de conflitos entreos dois model os denegócio foi estimado com base nas percepções dos executivos sobre os vários riscos que a empresa estabelecida poderia enfrentar para competir simultaneamente com ambos os negócios. A Tabela lista os dez conflitos ou riscos que mensuramos.

Pediu-se aos respondentes que avaliassem a dificuldade de tentar competir simultaneamente nas duas posições estratégicas em sua indústria com base nos risco subjacentes. Uma escala de cinco pontos (Likert) foi usada para medir a extensão (ou tamanho) de cada um dos riscos, classificando-os de "Pouco" (=1) a "Muito" (=5). Os escores para os dez itens foram classificados a fim de oferecer um valor médio para o nível de conflitos para cada empresa estabelecida da amostra. Q uanto maior era o vaIor, maior o nível de conflitos entre o negócio da empresa existente e o novo modo de competir na indústria. Os valores foram classificados de 1 a 4,44, com uma média geral de 1,91 (alfa de Cronbach =0,87).

Para mensurar a similaridade estratégica entre os dois mercados aos quais os dois modelos de negócio

\section{Tabela: Conflitos potenciais entre dois model os de negócio diferentes}

Risco de canibalização da base existente de clientes

Risco de destruir ou minar o valor da rede existente de distribuição

Risco de comprometer a qualidade dos serviços oferecidos aos clientes

Risco de minar a imagem ou reputação da empresa e do valor associado a ela

Risco de destruir a cultura geral da organização

Risco de acrescentar atividades que podem confundir os empregados e os clientes com respeito aos incentivos e prioridades da empresa

Risco de perda de foco da organização ao tentar fazer tudo para todo mundo

Risco de desviar os clientes das atividades de alto valor para atividades de margem baixa

Risco de legitimar o novo negócio, criando então um incentivo para outras empresas também entrarem nesse mercado 
estavam buscando atender, seguimos a lógica e as recomendações de diversos pesquisadores acadêmicos que argumentam que o relacionamento entre os dois mercados deveria ser medido no nível de ativos estratégicos, e não no nível do mercado. ${ }^{17}$ O peracionalizamos o grau de relacionamento estratégico com base em três categorias abrangentes dos ativos estratégicos: (1) ativos de clientes (tais como reputação dos serviços, lealdade do cliente, consciência da marca e bom relacionamento com o consumidor); (2) ativos de canal (tais como acesso a canais de distribuição e redes de suprimento, e bons relacionamentos de distribuição/rede); e (3) ativos de processo (tais como cadeias de suprimento eficientes para pedidos feitos ou produtos padronizados e serviços, capital humano e o nível geral de habilidades da força de trabalho).

Oito diferentes indicadores desses ativos estratégicos foram identificados para cada uma das 11 indústrias da amostra. Esses indicadores incluíram:

- a medida em que a empresa oferece suporte de serviços pessoais a seus clientes;

- a medida em que a empresa oferece suporte de serviços técnicos para seus clientes;

- o nível em que a oferta de produto

ou serviço deve ser customizada ou não;

- a medida em que a compra era uma maior ou menor compra para o cliente;

- média de propaganda;

- impulso do marketing (isto é, a importância de manter um alto de nível de gastos de marketing com canais de distribuição e infra-estrutura associada);

- o nível de habilidades gerais da força de trabalho (isto

é, a importância de manter uma base de empregados com alta habilitação);

- a importância de ter uma equipe de baixo custo.

Pediu-se que os respondentes classificassem a importância desses indicadores de ativos estratégicos a fim de competir efetivamente (a) em um negócio tradicional e (b) no novo negócio. Uma escala de cinco pontos foi utilizada, classificando-se de "Nada importante" (=1) a "Muito im- portante" (=5).

Para medir o nível de relacionamento estratégico entre os dois negócios (ou seja, a medida em que os dois negócios enfatizam os mesmos ativos estratégicos), criamos uma variável contando o número de indicadores de ativos estratégicos considerados pelos executivos como "Importantes" ou "Muito importantes" para cada um dos dois negócios (isto é, aquel es indicadores que eram classificados como ' 4 ' ou ' 5 ' na escala para o negócio tradicional e para o novo negócio criado). A variável foi codificada de 0 (significando que nenhum dos oito indicadores foi considerado importante para ambos os negócios) a 8 (significando que todos os oito indicadores foram considerados importantes para os dois negócios). Q uanto maior fosse o valor dessa variável, maior seria o nível de relacionamento estratégico entre os dois negócios. ${ }^{18}$ Os valores foram classificados de 0 a 8 e a média foi de 3.8.

\section{novo modo de competi r, mas não no começo.}

Tendo cal culado essas duas variáveis para cada empresa, fomos capazes de mapear as empresas de nossa matriz. Como não há qual quer racionalidade sobre quais são os pontos de corte (entre conflitos menores/sérios e relacionamento baixo/alto), decidimos errar em benefício do lado conservador. Conforme relatado anteriormente, 0 valor médio de conflitos para a amostra inteira foi de 1,91 (na escala de 1 a 5). Por esse motivo, classificamos quaisquer valores acima de 3,5 como conflitos "sérios". Similarmente, 0 valor médio de relacionamento estratégico para a amostra inteira foi de 3,8 (na escala de 0 a 8). Por esse motivo, classificamos quaisquer valores acima de 5 como de relacionamento estratégico "alto".

N ossa tarefa final foi avaliar quais empresas foram bem-sucedidas em competir com modelos duplos de negócio e quais não foram. Para determinar "sucesso", usamos três abordagens complementares. 
Primeiro pedimos que todas as empresas respondentes avaliassem sua própria eficiência em adotar o novo modelo de negócio por meio de nove critérios de desempenho. Especificamente, pedimos que avaliassem se, ao abraçarem o novo modelo, elas: (a) evitavam que 0 novo negócio se expandisse no negócio tradicional e prejudicasse as operações existentes; (b) evitavam que os atuais clientes deixassem a empresa; (c) atraíram novos clientes; (d) aumentaram as receitas e a lucratividade; (e) desenvolveram novas habilidad es e competências; (f) aumentaram a qualidade dos produtos e serviços; (g)
Para reduzir o viés de auto-resposta, também empregamos uma terceira medida de sucesso: análise setorial (indústria) de sete empresas de gestão de fundos em Londres e Wall Street. Pediu-se que elas classificassem cada uma de nossas empresas respondentes em uma escala de "eficiência geral". Os analistas classificaram somente as empresas em setores que el es conheciam e usaram a mesma escala de 1 a 6 pontos. ${ }^{20}$

As empresas que classificaram a si mesmas com 6 na escala de "eficiência geral" ou com 5 e acima na escala cal culada como a média dos novos critérios de de-

\section{Preparar uma uni dade para o casamento é}

\section{o desafio que as empresas que escol hem a} integração por etapas devem enfrentar. Em comparação, o desafio que as empresas que escol hem a estratégia de separação enfrentam

\section{é preparar a unidade para o divórcio.}

sempenho e também receberam uma classificação de 6 dos analistas foram selecionadas como respondentes bem-sucedidos. Esse esquema de triagem gerou um total de 17 empresas que foram consideradas como tendo respondido de forma bemsucedida ao novo modelo de negócio. Sete das empresas bem-sucedidas foram colocadas no quadrante $A, 3$ no quadrante $B, 5$ no quadrante cortaram custos; (h) tornaram-se mais competitivas na indústria como um todo; e (i) tornaram-se parte de um novo e crescente negócio. Uma escala de seis pontos foi utilizada, classificando de "Muito ineficiente" (=1) a "Muito eficiente" $(=6)$. Um escore médio de nove itens foi calculado como a medida para a análise estatística. Quanto maior fosse o escore, maior seria a eficiência da empresa em adotar o novo modelo de negócio e competir em duas posições estratégicas simultaneamente. Valores foram classificados de 2,56 a 6 , com uma média geral de 4,6 (alfa de Cronbach $=0.72$ ).

Segundo, pedimos que as empresas respondentes nos dessem uma avaliação geral (em uma escala de 0 a 6) sobre quão eficientemente pensavam ter adotado o novo modelo de negócio. Embora as medidas de auto-avaliação tais como as usadas aqui sejam sujeitas a vieses, elas também são apresentadas como confiáveis. ${ }^{19}$
$C$ e 2 no quadrante $D$. Cinco dessas empresas já eram 0 tema da pesquisa de campo empreendida antes que 0 questionário fosse enviado. Sessenta ou mais empresas de todos os quatro quadrantes de nossa matriz foram selecionadas nesse estágio para estudos adicionais na pesquisa de campo. N osso objetivo em falar com os executivos dessas empresas era compreender o que diferenciava as empresas bem-sucedidas em cada quadrante. O s insights ap resentad os neste artigo são baseados principal mente nessa pesquisa de campo e parcial mente em nossa análise dos dados dos questionários.

\section{Agradecimentos}

Agradecemos a Sumantra Ghoshal, Erik Larsen, John Morecroft e Freek Vermeulen, editores desta revista, e aos dois revisores anônimos pelos vários e construtivos comentários e consel hos. 


\section{Notas}

1. Ver Porter, M. E. Competitive strategy. New York: Free Press, 1980; e Porter, M. E. What is strategy? Harvard Business Review, p. 61-78, Nov/ Dez, 1996.

2. Ver Christensen, C. M. The innovator's dilemma: When new technologies cause great firms to fail. Boston: Harvard Business School Press, 1997.

3. Ver Burgelman, R.; Sayles, L. Inside corporate innovation. New York: The Free Press, 1986; e Gilbert. C.; Bower, J. Disruptive change: When trying harder is part of the problem. Harvard Business Review, p. 94-101, Maio, 2002.

4. Ver Porter, M. E. What is strategy? Harvard Business Review, 77, N ov/ Dez, 1996.

5. Ver Day, J. D. et al. The innovative organization: Why new ventures need more than a room of their own. The M cKinsey Quarterly, 2, p. 21, 2001.

6. Ver Iansiti, M.; McFarlan, F. W.; Westerman, G. Leveraging the incumbent's advantage. Sloan M anagement Review, 44(4), p. 58, 2003.

7. Ver Tushman, M. L.; O'Reilly III, C. A. Ambidextrous organizations: $M$ anaging evolutionary and revolutionary change. California M anagement Review, 38(4), p. 8-30, 1996.

8. Ver Lawrence, P.; Lorsch, J. Organization and environment. Boston: Harvard Business School Press, 1967.

9. Oferecemos definições mais precisas de "conflitos" e "similaridade estratégica" no Apêndice. Conflitos incluem tradeoffs no nível da cadeia de valor, bem como conflitos de canais e marcas. Similaridade estratégica envolve relacionamento de mercado, bem como similaridade de recursos.

10. Uma matriz similar ajuda os gestores a determinar se uma empresa deveria usar uma equipe com profissionais pesos-pesados (ou pesos-leves) dentro ou fora da organização existente a fim de gerenciar um modelo de negócio diferente pode ser encontrado em Clayton Christensen e Michael Overdorf. Meeting the challenge of disruptive change. Harvard Business Review, pp. 67-76, Mar/Abr, 2000. N ossa matriz difere da deles em duas dimensões importantes. Primeiro, o modelo deles leva em consideração somente a importância dos conflitos (nos valores e processos). Em contrapartida, argumentamos que a decisão com respeito ao que fazer é determinada não apenas pelos conflitos, mas também pela possibilidade de explorar sinergias entre os dois mercados aos quais os dois modelos de negócio atendem. Nesse sentido, nosso modelo baseia-se na tradição intelectual iniciada por Lawrence e Lorsh. Segundo, nosso modelo leva o tempo em consideração; defendemos que, sob certas circunstâncias, seria melhor separar (integrar) o novo modelo de negócio em primeiro lugar e depois integrá-lo (separando-se da) organização existente.

11. Ver Lawrence \& Lorsch, op. cit.

12. Ver Gulati, R.; Garino, J. Get the right mix of bricks and clicks. Harvard Business Review, p. 107-14, Maio/Jun, 2000.

13. Edward Jones atende a investidores individuais exclusivamente por meio de uma extensa rede de mais de 4 mil agências em todos os cinqüenta estados norte-americanos.
14. Kelly, E. Edward Jones and me. Fortune, 12, p. 145, Jun, 2000.

15. Ver Dutton, J. E.; Jackson, S. E. Categorizing strategic issues: Links to organizational action. Academy of Management Review, 12(1), p. 76-90, 1987.

16. Ver Gilbert \& Bower, op. cit., p. 94-101.

17. Ver, em particular, Markides, C. C.; Williamson, P. W. Related diversification, core competences, and corporate performance. Strategic Management Journal, 15, p. 149-65, 1994; eVerdin, P. J.; Williamson, P. J. Core competences, competitive advantage, and market analysis: Forging the links. In Hamel, G.; Heene, A. (Eds.). Competence-based competition. New York: John Wiley \& Sons Ltd., p. 77-110, 1994.

18. Também mensuramos o grau de relacionamento tomando a média das diferenças absolutas entre o velho e o novo negócio em cada uma das escalas. Isso não afetou a classificação das empresas de nossa amostra na Figura 1.

19. Ver Dess, G. S.; Robinson, R. B. M easuring organizational performance in the absence of objective measures. Strategic M anagement Journal, 5 , p. 265-73, 1984; e Venkatraman, N.; Ramanujam, V. Measurement of business performance in strategic research: A comparison of approaches. Academy of M anagement review, 11(4), p. 801-14, 1986.

20. Pediu-se também aos analistas que identificassem as empresas (não necessariamente as empresas da amostra) nos setores que haviam trabaIhado e que, em sua opinião, responderam à invasão do novo modelo de negócio de um modo eficiente. Quatro empresas adicionais foram identificadas para posteriores investigações por meio de estudo de campo.

Artigo originalmente publicado sob o título Competing with dual business models: A contingency approach, na The Academy of Management Executive, v. 18, n. 3, p. 22-36, agosto de 2004. Copyright 2005 Academy of M anagement. Todos os direitos são reservados. Nenhuma parte deste artigo pode ser reproduzida por qualquer meio ou forma sem a permissão por escrito da Academy of Management. Para obter autorização, entre em contato com 0 Copyright Clearence Center: www.copyright.com.

\section{Texto traduzido por Pedro F. Bendassolli}

\section{Constantinos Markides}

Prof. de Estratégia e Gestão Internacional na London Business School

MBA pela Harvard Business School

E-mail: cmarkides@london.edu

Constantinos D. Charitou

Ph.D. em Estratégia e Gestão Internacional pela London Business School

E-mail: costas.charitou@nplanits.com 